\title{
Subject Status Group Identifier
}

National Cancer Institute

\section{Source}

National Cancer Institute. Subject Status Group Identifier. NCI Thesaurus. Code 6117657.

A character or string that represents a subject status findings group. 